\title{
The Importance of Revising Policy of Minimum Age of Marriage: A Philosophical, Sociological and Juridical Argumentation
}

\author{
Siti Rofiah ${ }^{1^{*}}$ \\ ${ }^{1}$ Faculty of Law and Syari'a, Islamic State University of Walisongo, Semarang, Indonesia
}

\begin{abstract}
The policy of minimum age for marriage is set out in Act No. 1 of 1974 On Marriage, which is 19 years for men and 16 years for women. According to Act No. 35 of 2014 On Child Protection, the age of 16 is still a child. Therefore, the policy of minimum age for marriage is open up the potential for child marriage. Various previous researches indicate that child marriages has the potential to cause negative impacts for both the child itself and the social life widely. Accordingly, revising the policy of minimum age for marriage is very important. This study uses the socio legal method where the law is not only conceptualized as a set of rules, but also as a behavior. In this method, legal validity is not only determined by norms, but also from the facts that grow and develop in society. The results showed that revising of minimum age for marriage has a philosophical, sociological and juridical basis. Child marriage has an impact on social life because it can lead to a cycle of sustainable poverty, increased illiteracy, poor health to future generations, and robbing of wider community productivity both in the short term and long term.
\end{abstract}

\section{Introduction}

Child marriage prevalence in Indonesia remains high, seventh rank in the world and second in ASEAN after Cambodia [1]. According to UNICEF, one in seven girls in Indonesia is married before the age of 18 [2]. With the same conclusion, Indonesia Basic Health Research 2013, revealed that among women aged 10-54 years, 2.6\% were first married less than 15 years of age, and $23.9 \%$ were married at the age of 15-19 years. This means that around $26 \%$ of underage women are married before the functions of their reproductive organs develop optimally [3].

The high prevalence of child marriage is a serious problem because it can potentially violate the rights of children, such as rights in health (the risk of the impact of giving birth in

\footnotetext{
*Corresponding email : siti_rofiah@walisongo.ac.id
} 
early pregnancy, sexual and reproductive health disorders), rights in education (unable to access education), economic rights (low human resources causes poverty), rights of security (risk of experiencing domestic violence) and so on. They experience poor conditions for all social and economic indicators compared to girls who marry at sufficient age. This bad impact will also be experienced by their children and can continue to the future generations.

The effort to eliminate child marriages is not easy because Indonesia's 1974 Marriage Law sets the legal marriage age at 16 years old for girls and 19 years old for boys [4], contradicting the child protection law that illegalizes parents from marrying off children below 18 years old [5]. It gets worse as the legislation also allows children under 16 years old to get married as long as their parents apply for, and the state court grants dispensation to them [6]. Data from the Supreme Court shows that in 2012 there were 9,632 cases that parent request permission to allow their children to get married, or 2.38 percent of the total cases handled throughout the Islamic courts as much as 404.857 cases [7].

The stipulation of marriage age and dispensation (exemption) policy on Act No. 1 of 1974 on Marriage is one of the factors that child marriage which causes many negative impacts and it continous to be practised. Ideally the legal marriage age should be raised to 21 years old, or at least 18 years as stipulated in the Convention on the Rights of the Child. Considering this, the Indonesian government need to take effort to this problem that remains widespread. This paper will present the philosophical, sociological and juridical arguments on the importance of revising the stipulation of marriage age and dispensation (exemption) policy of Indonesia's 1974 marriage law.

\section{Objective of the study}

This study aims to give an explanation about the importance of revising the minimum age for marriage and dispensation policy in Act No. 1 of 1974 on Marriage with the philosophical, sociological and juridical argumentation.

\section{Methodology}

This study employs the socio-legal method that the law is not only conceptualized as a set of rules, but also as a behavior [8]. With this method, legal validity is not only determined by the norms, but also by the facts which grow and develop in society. This method appears as a variant of legal research methods that bridge the dichotomous tendency between doctrinal and non-doctrinal approaches that one of them employs a normative approach and the other only employs an empirical approach.

With the guidance, there are three steps to do. First is conducting the philosophical studies about the meaning and purpose of marriage. Second is an observation of the impact of child marriage in social life through previous research or studies. Third is reviewing critically with the textual studies of legislation and policies taken from the written law, namely article 7 , paragraph (1) and (2) of the Marriage Law and its conflict with the policy of child protection system that has been regulated in other various laws and regulations.

\section{Discussion}

Child marriage is defined as a marriage that occurs before a child reaches the age of 18 [9]. Marriage at a young age forces girls into adulthood before they are emotionally or physically mature, leading to a range of harmful physical and psychological effects and a limitation of 
a range of their rights. Child brides are often expected to bear children soon after marriage, which makes them vulnerable to pregnancy and childbirth complications because their bodies are not physically ready. Therefore, increasing the minimum age is necessary to limit child marriage, and this is the argumentation.

Therefore, increasing the minimum marriage age is necessary to limit child marriage, and this is the argumentation.

\subsection{Philosophical Argument}

Marriage is a very strong agreement (mitsaaqan ghalidha), as stated in Quran Surah AnNisa/4:21. This message is then adopted in the Compilation of Islamic Law which states that marriage is a very powerful contract to obey Allah's commands and to perform the worship [10]. This is an explanation of the term "bonding in" contained in the formulation of the marriage law which means the marriage contract is not merely a civil agreement, but there is a substantial aspect of religiosity through the phrase "God Almighty", so marriage is a worship to God. It can be understood that in the perspective of Islamic law, a marriage has a double commitment, the first is human commitment (responsible to husband/wife, family, and state) and the second is divine commitment (responsible to God).

To have this commitment, certainly, it takes physical and mental readiness for being brides, one of them is marked by a sufficient age. Al-Qur'an and hadiths do not explicitly state what is the age limit of prospective brides, but implicitly Islamic law requires prospective bride to be mature, mentally and physically ready, also apprehend the meaning and purpose of marriage. Not setting a minimum age limit for a child to enter into a marriage can actually mean that the law gives Muslim, the freedom to adjust the problem to the cultural and social character of the local community [11].

Almost all clerics believe that one of the conditions that must be fulfilled by both of brides is that they have reached baligh, even though there are differences of opinion in interpreting baligh in terms of age. Every opinion is based on the experience of life and the place where the opinion is expressed. Imam Shafi'i, for example, who is domiciled in Baghdad and Egypt, stated that everyone in those areas is usually married when they are already being baligh or after getting menstruation, with an age range of 10 to 15 years. This is contrast for Imam Hanafi who lives and interacts in a cosmopolitan city. He describes that most women in this kind of city get married between the ages of 18 and 22, and the limitation age is more mature than the Baghdad community. At this age range, most women can make their own decisions. However, Imam Maliki set the age of 17 years for both the bride and groom [12].

Based on the perspective of Islamic law, at the beginning, the law of marriage is mubah (preferable). Then it can change becoming compulsory (wajib), recommended (sunnah), to forbidden (haram) in certain circumstances, depending on maslahat (for the goodness of humanity) [13]. Marriage becomes sunnah if it is intended to imitate the Prophet Muhammad SAW and a commitment to bring the goodness to themselves and family. It can be compulsory if it is the only way to avoid someone from something that is prohibited. However, getting married can also be haram (forbidden) if it really influences someone to do something forbidden, such as violence, injustice or tyranny [14].

In Islam, both the Qur'an and Hadith state that seeking knowledge is an obligation. Anas ibn Malik reported:

"The Messenger of Allah, peace and blessings be upon him, said: seeking knowledge is an obligation upon every Muslim" [15].

Child marriage causes school dropout, especially for girls. Girls tend to drop out of school shortly after the marriage. There are practical and legal obstacles for married girls to go back to school. Girls who live far or have children to look after may not be able to resume their education. Sometimes, the stigma of pregnancy keeps girls from returning to school. Thus, 
child marriage breaks the Islamic law because it leaves the obligation and does what is forbidden.

\subsection{Sociological Argument}

Child marriage results in various negative impacts, both for the child itself and for society in general. Child marriage effectively ends a girl's childhood, curtails her education, minimizes her economic opportunities, increases her risk of domestic violence, and puts her at risk for early, frequent, and very high-risk pregnancies. Physical and psychological readiness of women for marriage is at least 20 years old. Marriage before the age of 20 years for women increases the risk of maternal and child health. Research conducted by Santhya et al., showed that women who were married before the age of 18 years are at risk of physical violence, sexual violence, miscarriage and stillbirth [16].

The research has conducted by Plan Indonesia in collaboration with UGM Center for Population and Policy Studies (PSKK) in 2011 entitled 'Practices of Early Marriage in Indonesia' in eight regions (Indramayu, Grobogan, Rembang, Tabanan, Dompu, Sikka, Lembata, and Timur Tengah Selatan). It reveals the impact of child marriage can be seen in several aspects. First is related to reproductive health. Pregnancy due to child marriage is a high risk pregnancy. Girls aged 10-14 have a five times greater chance of dying, during pregnancy or childbirth, compared to women aged 20-25 years. Second is mental health. Child marriage disproportionately affects girls and has an impact on their mental and physical health for the rest of their lives. They are often stress when leaving their families and are responsible for their own families. Third, girls who marry before 18 are more likely to experience domestic violence. As many as $44 \%$ of girls who have early marriage experience high-frequency domestic violence. The rest, $56 \%$ of girl experience domestic violence in low frequency [17].

Complementing previous research, another study entitled "The Impact of Child Marriage in Indonesia” in eight cities (DKI Jakarta, Lampung, Semarang, Banyuwangi Sukabumi, NTB, South Kalimantan, and North Sulawesi) in 2014 reveals more concerned resuls. In Jakarta for example, unplanned pregnancies occur at the age of marriage with a young age of 16 to 20 years old amounting to $51.7 \%$, a length of marriage of less than 10 years as much as $42.5 \%$ of all unplanned pregnancies, around $6.71 \%$ were intentionally aborted. Based on the infant mortality data reported by Puskesmas (government-mandated community health clinics) in DKI Jakarta province, the infant mortality rate per 1,000 live births (reported) was 1.0. East Jakarta was recorded as the region with the highest number of infant deaths, which were 52 babies (2009). In 2013, East Jakarta had the highest maternal mortality rate with 31 people died. In 2013, there were 93 mothers died in DKI Jakarta. ${ }^{[18]}$

These data above open our eyes that child marriage has many negative impacts, such as increasing the vulnerability of girls to physical, sexual and mental violences, increasing the risk of girls to diseases and deaths associated with early pregnancy and childbirth, and so on.

\subsection{Juridical Argumentation}

The government of Indonesia has signed a number of international commitments (binding or not binding) including CEDAW(Convention on the Elimination of All Forms of Discrimination Against Women), the Beijing Declaration, the ICPD (International Conference on Population and Development) and the MDGs (Millenium Development Goals). However, all are not directly linked to age of marriage, the CRC (Convention on the Rights of the Child) and CEDAW directly address the issue. Moreover, the Government of Indonesia is also a signatory state to the International Convention on Economic and Cultural 
rights (ICESCR) and the International Convention on Civil and Political Rights (ICCPR). A national machinery has been established to implement CEDAW and other related provisions to protect children in the International Convention, which includes the Ministry of Women's Empowerment and Child Protection and the Child Protection Commission.

There are basic principles of international law that a state party to an international treaty must ensure that its own domestic law and practice are consistent with what is required by the treaty. In some cases, the treaty may give general guidance on the measures to be taken. According to the1974 Indonesian Marriage Act and the 1991 Compilation of Islamic Law, the legal age of marriage is set at 16 for girls and 19 for boys (article 7 of 1974 Marriage Act). However, the same Act allows girls and boys below 16 and 19 to be wedded if the parents have received permission from the court or marriage officer (article 7.2). This measures legalizes child marriages especially for girls and it is absolutely against the CRC and CEDAW. There are four general principles of child protection on the Convention on the Rights of the Child which will be violated by that provision, as follows:

1. Nondiscrimination, which means that all children have equal rights to develop their potential in all situations and at all times.

2. The best interests for children must be the main consideration in making a decision that affects children (Best Interests of the Child).

3. The right to survival and the right to develop the potential that exists in children (The Right to Life, Survival and Development).

4. Appreciation for children's participation in expressing themselves because children have the right to be heard and respected, and have the opportunity to express opinions in accordance with their views about decisions that affect them (Respect for the views of The Child).

Thus, revising the minimum age limit in marriage is a must as a form of consistency in the obligations of states parties in harmonizing national law with ratified international conventions.

Harmonization of law is also needed not only within the national law for the international conventions, but also between national laws. Basically, the content of the laws and regulations must reflect the principle of legal certainty, order, harmony and balance, [19] because every regulation does not stand itself, it always has links with other laws and regulations. If there are two or several laws that clash or overlap, then this can lead to nonconducive legal conditions. The stipulation between marriage age and dispensation (exemption) policy on Act No. 1 of 1974 on Marriage is contrary to the provisions of the 2014 Child Protection Act, consequently there are still many child marriages, and and many rights of children will be violated.

\section{Conclusion}

The revision of minimum age limit for marriage and marriage dispensation has a philosophical, sociological and juridical basis. Child marriages can cause children losing the right to education, the right to live free from violence and harassment (including sexual violence), the right to health, and the right to be protected from exploitation. In addition to violating children's rights, child marriage also has an impact on social life because it can lead to a cycle of sustainable poverty, increased illiteracy, poor health to future generations, and jeopardizing wider community productivity, both in the short and long term. That is why the revisions to this provision are needed. 


\section{References}

1. M. Z. Rakhmat, Indonesia's Problem with Child Marriage, https://www.asiasentinel.com/society/indonesia-child-marriage-problem/

2. UNICEF, State of the World's Children, (2016)

3. National Institute of Health Research and Development, Ministry of Health, Indonesia Basic Health Research (2013)

4. Act No. 1 of 1974 On Marriage (articel 7 (1)).

5. Convention on the Rights of the Child

6. Act No. 1 of 1974 On Marriage (articel 7 (2)).

7. Indonesian Legal Aid Association for Women (APIK), Early and Forced Marriages in Republic of Indonesia, A brief submitted to the Office of the High Commissioner for Women's Rights and Gender Section (WRGS) at the 26th session of the Human Rights Council, tt.

8. Sulistyowati Irianto and Shidarta (ed), Metode Penelitian Hukum, Konstelasi dan Refleksi (Penerbit Yayasan Obor Indonesia, Jakarta, 2009).

9. Convention on the Rights of the Child

10. Direktorat Pembina Peradilan Agama, Kompilasi Hukum Islam di Indonesia, (Jakarta, 2003).

11. Rohidin, Batas Usia Minimal Kawin dalam Perspektif Hukum Islam (Departemen Hukum Dasar FH UII dan Pusat Studi Gender UII, Yogyakarta, 2008).

12. M. J. Mughniyyah (Terj. Affif Muhammad), Fiqh Lima Mazhab (Basrie Press, Jakarta, 1994).

13. Ibn Majah, Muhammad b. Yazid, Al-Sunan, Kitab al-Nikah (Istanbul, Dar al-Dawa'h, $1401 \mathrm{H})$.

14. https://mubaadalah.com/2017/06/pendidikan-wajib-menikah-mubah/ accessed on 21 August 2018

15. S. Ibn Mājah Hadith No: 224

16. K. G. Santhya, U. Ram, R. Acharya, S. J. Jejeebhoy, F. Ram and A. Singh, Journal of International Perspectives on Sexual and Reproductive Health, 36, 132-139, (2010).

17. PSKK UGM dan Plan Indonesia. Laporan Akhir Pernikahan Anak di Indonesia, (Yogyakarta, 2011)

18. Djamilah, Reni Kartikawati, Dampak Perkawinan Anak di Indonesia, J. Studi Pemuda - 3, 1 (2014)

19. Articel 6 (1) Law of The Republic of Indonesia No. 12 of 2011 Concerning Making Rules. 